\title{
ASPEK EKONOMI PENERAPAN TEKNOLOGI PUPUK SRF NPK KAPASITAS 10.000 TPY Di KABUPATEN BANTAENG SULSEL
}

\section{ECONOMIC ASPECT IMPLEMENTATION OF SRF- NPK FERTILIZER TECHNOLOGY CAPACITY 10.000 TPY IN BANTAENG DISTRICT, SOUTH SULAWESI}

\author{
Endro Wahju Tjahjono, Joko Hanuranto, \\ Pusat Teknologi Industri Proses \\ Deputi Teknologi Industri Rancang Bangun \& Rekayasa \\ Badan Pengkajian dan Penerapan Teknologi \\ Gedung Teknologi 2 Kompleks PUSPIPTEK, Serpong \\ Email : enwacah@yahoo.com. \\ jokohanurani@yahoo.com,
}

\begin{abstract}
Abstrak
Sektor pertanian dan perkebunan membutuhkan pupuk yang memadai dan dengan harga yang terjangkau untuk menjaga ketahanan pangan nasional. Industri pupuk saat ini terkendala oleh terbatasnya pasokan bahan baku, serta pada tingkat pengguna masih terjadi pola pemupukan yang kurang efisien. Pupuk SRF NPK adalah jenis pupuk yang dikembangkan untuk memberikan solusi khususnya pada elemen tabungan $\mathrm{N}$ (urea) dan untuk mendorong petani untuk menggunakan pupuk yang mengandung senyawa yang memiliki unsur hara yang lengkap $(\mathrm{N}, \mathrm{P}, \mathrm{K}$ dan zat gizi mikro). Aplikasi pupuk SRF NPK diharapkan dapat memberikan dampak ekonomi yang signifikan pada tingkat produsen pupuk, petani dan mampu memberikan multiplier effect di sektor-sektor pembangunan lainnya.
\end{abstract}

Kata kunci : Pupuk, SRF NPK, dampak ekonomi

\begin{abstract}
Agriculture and plantation sector requires adequate fertilizer and at an affordable price to maintain national food security. Fertilizer industry is currently constrained by the limited supply of raw materials, as well as at the user level is still happening fertilization patterns are less efficient. SRF NPK fertilizer is a type of fertilizer that was developed to provide solutions in particular on the savings element of $N$ (urea) and to encourage farmers to use fertilizers containing compound that has a complete nutrient elements ( $N, P, K$ and micro nutrients). SRF NPK fertilizer application is expected to provide significant economic impact (significant) level either fertilizer producers, farmers and able to provide a multiplier effect in other sectors of development.
\end{abstract}

Keywords : Fetilizer, SRF NPK, Economic impact

Diterima (received) : 4 Februari 2014, Direvisi (reviewed) : 12 Februari 2014,

Disetujui (accepted) : 25 Februari 2014

\section{PENDAHULUAN}

Sebagai sarana produksi pertanian, pupuk memiliki peranan sangat penting dalam meningkatkan produktivitas dan mutu hasil pertanian, khususnya tanaman pangan dan perkebunan sebagai tujuan Program Ketahanan pangan nasional. Sehingga ketersediaan pupuk di semua lokasi perlu diupayakan sesuai dengan prinsip 6 tepat (tepat jumlah, tepat tempat, tepat jenis, tepat harga, tepat waktu dan tepat mutu). Data kebutuhan pupuk untuk sektor pertanian tahun 2010 - 2025 yang dikeluarkan Kementrian Pertanian, kebutuhan pupuk urea secara nasional diperkirakan akan meningkat 
dari 6,785 juta ton pada 2010 menjadi 7,302 juta ton tahun 2015 dan akan terus meningkat menjadi 8,038 juta ton pada 2020 dan 9,155 juta ton pada tahun 2025. Sedangkan kebutuhan pupuk NPK secara nasional diperkirakan akan meningkat dari 8,1 juta ton pada 2010 menjadi 10,7 juta ton tahun 2015 dan akan terus meningkat menjadi 12,9 juta tob pada 2020 dan 20,0 juta ton pada tahun 2025. Peningkatan kebutuhan pupuk baik pupuk tunggal maupun majemuk/NPK tersebut tidak saja untuk kebutuhan pertanian tanaman pangan tetapi juga untuk memenuhi kebutuhan perkebunan dan hortikultura.

Seiring dengan meningkatnya kebutuhan pupuk nasional, kapasitas industri pupuk nasional harus terus ditingkatkan. Namun demikian meningkatnya kebutuhan pupuk nasional tersebut terkendala dengan sejumlah permasalahan baik di tingkat hilir pupuk (penggunaan pupuk) maupun ditingkat hulu (industri pupuk) maupun pada beban APBN diantaranya :

1. Di tingkat petani (penggunaan pupuk)

a.Penggunaan pupuk oleh petani tidak efisien

b. Pemakaian pupuk berlebihan oleh petani

c. Kerusakan struktur lahan (lingkungan)
d. Keterbatasan daya beli pupuk oleh petani

2. Di tingkat industri pupuk
a. Keterbatasan bahan baku pupuk (gas)
b. Usia pabrik yang relative tua
c. Tingginya penggunaan energi untuk produksi per ton pupuk

3. Subsidi pupuk yang masih tinggi

Slow Release Fertilizer (SRF) atau pupuk lepas lambat, yaitu suatu jenis pupuk yang mampu mengendalikan kecepatan pelepasan unsur-unsur hara yang mudah hilang akibat larut dalam air, menguap dan proses denitrifikasi terhadap pupuk itu sendiri menjadi salah satu solusi untuk mengatasi masalah ketersediaan dan ragam pupuk.

Sebagai upaya komersialisasi pupuk SRF NPK, BPPT bekerjasama dengan PemKab. Bantaeng Sulawesi Selatan untuk dapat mengoperasikan pabrik pupuk SRF NPK Kapasitas 10.000 Ton/Tahun. Diharapkan dengan dapat di opersionalkan pabrik tersebut oleh Pemkab Bantaeng, pupuk SRF dapat dilakukan komersialisasi di wilayah tersebut dengan target untuk dapat memenuhi sebagian kebutuhan pupuk di wilayah tersebut dan meningkatkan tingkat ekonomi masyarakat di wilayah tersebut..

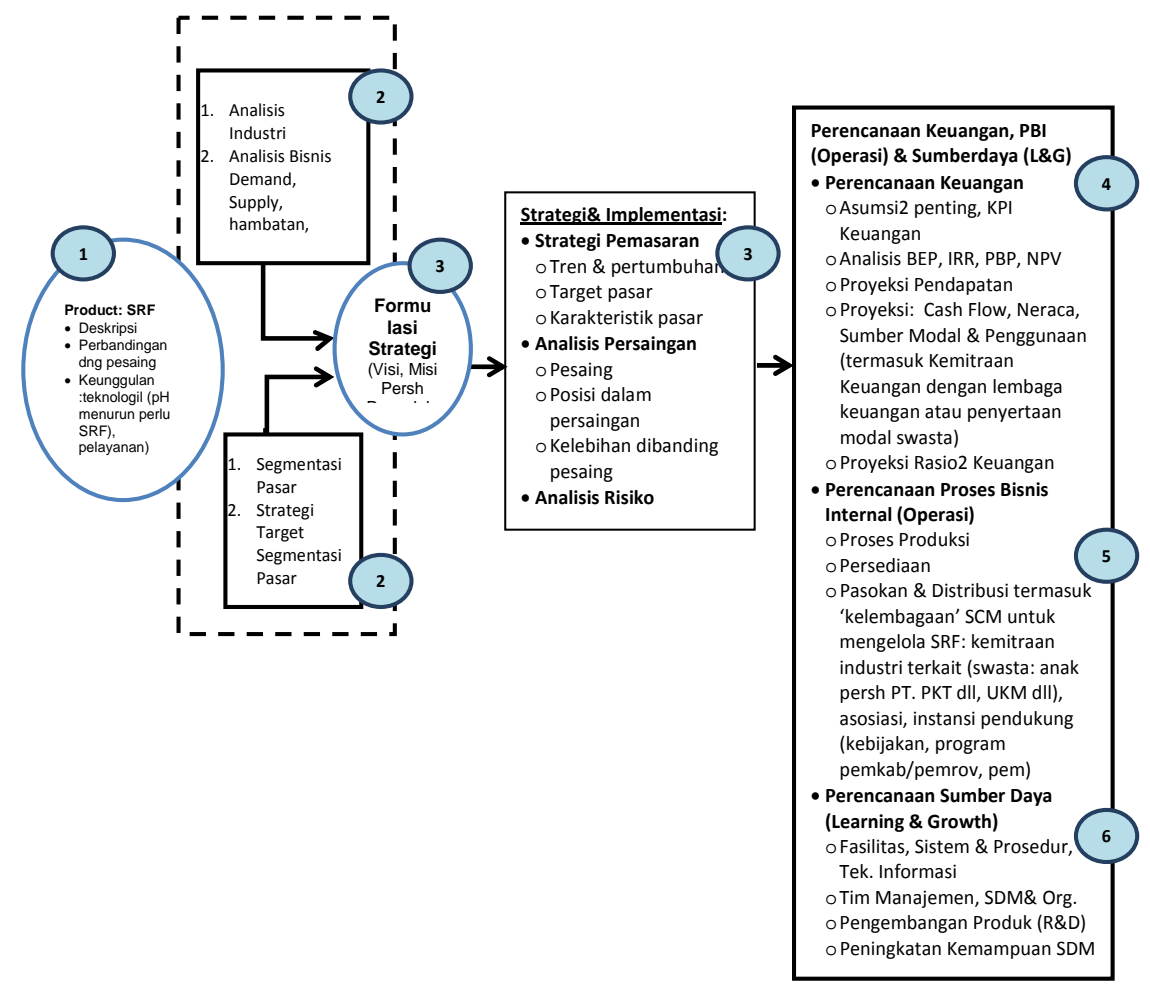

Gambar 1.

Diagram Analisis Ekonomi 


\section{BAHAN DAN METODE}

Analisis aspek ekonomi teknologi pupuk SRF NPK di uraikan dalam Gambar 1.di atas

Dalam diagram tersebut analisis ekonomis dan bisnis dapat dikelompokkan dalam beberapa tahap sebagai berikut :

1) Gambaran umum produk pupuk, berupa pupuk SRF NPK dengan keunggulan teknologi formulasinya maupun manfaat yang di dapatkan.

2) Analisis industry pupuk serta analisis suplly deman

3) Segmentasi pasar pupuk serta target pasar yang diharapkan.

4) Strategi dan perencanaan pemasaran.

5) Perencanaan keuangan
6) Perencanaan bisnis internal(operasional)

7) Perencanaan sumber daya

\section{HASIL DAN PEMBAHASAN}

\section{Keunggulan Pupuk SRF}

Pupuk lepas lambat (SRF) merupakan pupuk yang mempunyai kemampuan mengontrol untuk proses melepas unsur hara yang diperlukan tanaman. Sejumlah kelebihan penggunaan pupuk lepas lambat (SRF) adalah sebagai berikut :

Pupuk lepas lambat (SRF) merupakan pupuk yang mempunyai kemampuan mengontrol untuk proses melepas unsur hara yang diperlukan tanaman. Sejumlah kelebihan penggunaan pupuk lepas lambat (SRF) dapat lihat pada Tabel 1.

Tabel 1.

Gambaran Pupuk SRF NPK ${ }^{1)}$

\begin{tabular}{lll}
\hline \multicolumn{2}{c}{ Kelebihan SRF } & \multicolumn{1}{c}{ Keuntungan bagi pengguna } \\
\hline Berbentuk Granule & - & Petani sudah terbiasa dengan bentuk pupuk \\
& granule \\
Pelepasan unsur & - & Mudah bagi petani dalam aplikasinya. \\
hara terkontrol & - & Menghemat penggunaan unsur hara \\
Mengandung Zeolite & - & Memperbaiki truktur tanah akibat akumulasi pupuk \\
(sebagai matrix), & & kimia \\
Mudah diproduksi & - & Mengurangi kerusakan lingkungan persawahan \\
dalam skala kecil- & & Bagi usaha perkebunan dapat di produksi dekat \\
menengah & - & Mengurangi biaya produksi/ biaya pemupukan \\
Teknologi produksi & - & Dapat di buat oleh bengkel bengkel lokal \\
sederhana & - & Dapat dioperasikan dengan sedikit pelatihan \\
Harga bersaing & - & Tidak menambah biaya pemupukan bagi petani \\
dengan kompetitor & & \\
Periode pemupukan & - & Mengurangi tenaga pemupukan \\
cukup 1 kali & - & Mengurangi biaya tenaga kerja \\
\hline
\end{tabular}

\section{Kebutuhan pupuk Subsidi di Sulawesi Selatan}

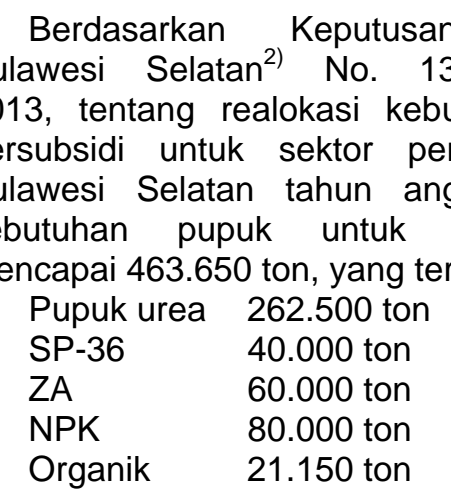

Untuk wilayah Bantaeng kebutuhan pupuk untuk tahun 2013 mencapai 12.080 ton, yang terdiri atas :
a. Urea
8.955 ton
b. SP-36
240 ton
c. ZA
2.010 ton
d. NPK
675 ton
e. Organik 200 ton

Untuk wilayah Sulawesi Selatan bagian Selatan (Sekitar Bantaeng) yang meliputi Bulukumba, Jeneponto, Takalar, Gowa, kebutuhan pupuk untuk wilayah tersebut untuk tahun 2013 mencapai 79.855 ton, yang terdiri atas : 

a. Urea $\quad 79.855$ ton
b. SP-36 4.570 ton
c. ZA 12.915 ton
d. NPK 7.485 ton
e. Organik 1.475 ton

Rincian kebutuhan pupuk di wilayah Kab. Bantaeng dan Sulsel dapat dilihat pada Tabel 2 dan Tabel 3.

Tabel 2.

Kebutuhan Total Pupuk Subsidi Sektor Pertanian Sulawesi Selatan Th. $2013^{4,6)}$

\begin{tabular}{lrrrrr}
\hline \multicolumn{1}{c}{ Sub Sektor } & \multicolumn{5}{c}{ Alokasi } \\
& \multicolumn{1}{c}{ Urea } & \multicolumn{1}{c}{ Sp-36 } & \multicolumn{1}{c}{ ZA } & \multicolumn{1}{c}{ NPK } & Organik \\
\hline Tanaman Pangan & 170.625 & 22.800 & 38.489 & 54.276 & 16.157 \\
Hortikultura & 23.625 & 6.800 & 2.943 & 8.029 & 1.433 \\
Perkebunan & 57.750 & 8.400 & 16.801 & 15.357 & 2.583 \\
Peternakan & 7.875 & 400 & 1.493 & 1.480 & 458 \\
Perikanan & 2.625 & 1.600 & 274 & 858 & 519 \\
\multicolumn{1}{c}{ Jumlah } & 262.500 & 40.000 & 60.000 & 80.000 & 21.150 \\
\hline
\end{tabular}

Tabel 3.

Kebutuhan Total Pupuk Subsidi Sektor Pertanian Sulawesi Selatan Th.2013 Per Kabupaten ${ }^{4,6}$

\begin{tabular}{|c|c|c|c|c|c|}
\hline \multirow[b]{2}{*}{ Kabupaten/kota } & \multicolumn{5}{|c|}{ Alokasi } \\
\hline & Urea & Sp-36 & $Z A$ & NPK & Organik \\
\hline Selayar & 1.050 & 60 & 65 & 50 & 65 \\
\hline Bulukumba & 12.885 & 1.710 & 2.300 & 2.080 & 250 \\
\hline Bantaeng & 8.955 & 240 & 2.010 & 675 & 200 \\
\hline Jeneponto & 17.665 & 880 & 3.050 & 880 & 350 \\
\hline Takalar & 12.195 & 715 & 2.720 & 1.775 & 325 \\
\hline Gowa & 28.155 & 1.025 & 2.835 & 2.075 & 350 \\
\hline Sinjai & 4.005 & 1.020 & 1.320 & 915 & 450 \\
\hline Bone & 29.475 & 7.500 & 7.900 & 14.250 & 3.200 \\
\hline Maros & 10.480 & 1.230 & 2.120 & 3.560 & 475 \\
\hline Pangkep & 7.795 & 1.435 & 2.000 & 2.200 & 2.000 \\
\hline Barru & 4.460 & 815 & 1.000 & 1.500 & 510 \\
\hline Soppeng & 13.260 & 2.280 & 3.650 & 3.490 & 1.450 \\
\hline Wajo & 22.530 & 3.730 & 4.250 & 6.000 & 950 \\
\hline Sidrap & 20.675 & 2.930 & 3.470 & 5.425 & 850 \\
\hline Pinrang & 19.750 & 2.530 & 3.150 & 5.325 & 1.200 \\
\hline Enrekang & 6.590 & 1.535 & 2.800 & 4.000 & 750 \\
\hline Tana Toraja & 2.085 & 605 & 850 & 1.100 & 225 \\
\hline Toraja Utara & 1.865 & 600 & 930 & 850 & 175 \\
\hline Luwu & 8.630 & 2.250 & 2.850 & 5.800 & 650 \\
\hline Luwu Utara & 16.665 & 2.600 & 5.200 & 7.900 & 3.250 \\
\hline Luwu Timur & 11.795 & 3.590 & 4.315 & 9.000 & 2.750 \\
\hline Kota Makasar & 500 & 140 & 150 & 250 & 125 \\
\hline Kota Pare-Pare & 200 & 115 & 50 & 100 & 75 \\
\hline Kota Palopo & 835 & 465 & 1.015 & 800 & 525 \\
\hline Jumlah & 262.500 & 40.000 & 60.000 & 80.000 & 21.150 \\
\hline
\end{tabular}




\section{Kebutuhan pupuk non subsidi di Sulawesi Selatan}

Berdasar data BKPM $^{5}$ (Badan Koordinasi Penanaman Modal), luas Iahan perkebunan yang meliputi perkebunan kelapa sawit, kakao, tebu, kopi, cengkeh dan karet seluas 423.821 ha. Data hasil produksi perkebunan dan produktivitas lahan dapat dilihat pada Tabel 3. Dimana pada Tabel tersebut rata rata produktivitas dari tanaman perkebunan masih lebih rendah dari produktivitas yang ideal dari masing masing komoditas tersebut. Dengan perkiraan kebutuhan pupuk berkisar antara 400 - 800 kg/ha, maka kebutuhan pupuk untuk sector perkebunan diperkirakan sebesar 170.000 ton hingga 340.000 ribu ton.

Untuk tanaman jagung, produktivitas rata rata mencapai 4.55 ton/ha, dengan luas lahan mencapai 300.000 ha, diperlukan sekitar 120.000 ton pupuk. Kebutuhan ini baru dipenuhi sebagian dengan pupuk subsidi, sehingga masih terdapat kekurangan pupuk untuk tanaman jagung yang mengakibatkan produktifitasnya masih cukup rendah.

Tabel 4.

Luas Lahan Dan Kebutuhan Pupuk Sektor Perkebunan.

\begin{tabular}{lrrrrr}
\hline Komoditas & \multicolumn{1}{c}{$\begin{array}{c}\text { Luas } \\
\text { Lahan }\end{array}$} & $\begin{array}{c}\text { Produksi } \\
\text { Rata-rata } \\
\text { Ton/Tahun } \\
(2008-2012)\end{array}$ & $\begin{array}{c}\text { Produktivitas } \\
\text { Rata-rata } \\
\text { Ton/ha } \\
(2008-2012)\end{array}$ & $\begin{array}{c}\text { Perkiraan } \\
\text { Kebutuhan } \\
\text { Pupuk } \\
\text { kg/Ha }\end{array}$ & $\begin{array}{c}\text { Perkiraan } \\
\text { Kebutuhan } \\
\text { Pupuk } \\
\text { Ton/Tahun }\end{array}$ \\
\hline Kelapa Sawit & 12.093 & 31.760 & 2,63 & 400 & 4.837 \\
Kakao & 265.983 & 169.494 & 0,64 & 400 & 106.393 \\
Tebu(Ton Gula) & 2.646 & 27.737 & 10,48 & 400 & 1.058 \\
Kopi & 70.286 & 32.819 & 0,47 & 400 & 28.114 \\
Cengkeh & 58.708 & 11.079 & 0.19 & 400 & 23.483 \\
Karet & 14.105 & 8.263 & 0.59 & 400 & 5.462 \\
Total & 423.821 & & & & 169.528 \\
\hline
\end{tabular}

Tabel 5

Produksi Dan Produktifitas Jagung Di Sulawesi Selatan Th.2013

\begin{tabular}{lcr} 
Tahun & $\begin{array}{c}\text { Produksi } \\
\text { (Ton) }\end{array}$ & $\begin{array}{c}\text { Produksi } \\
\text { (Ton) }\end{array}$ \\
\hline 2008 & 1.195 .691 & 3,99 \\
2009 & 1.395 .742 & 4,66 \\
2010 & 1.343 .044 & 4,48 \\
2011 & 1.420 .154 & 4,74 \\
2012 & 1.457 .879 & 4,86 \\
Rata-rata & 1.362 .502 & 4,55 \\
\hline
\end{tabular}

\section{Analisis Pasar}

Melihat pada permasalahan harga pupuk, dimana pasar pupuk bukan merupakan pasar sempurna, tetapi telah terjadi intervensi dengan adanya harga subsidi, maka produk baru seperti pupuk SRF NPK belum bisa masuk pasar pupuk subsidi sebelum adanya regulasi yang mengaturnya, maka pupuk SRF NPK ditujukan untuk pasar pupuk non subsidi. Terkait dengan hal tersebut segmen pasar yang dapat dimasuki adalah sektor perkebunan, hortikultura dan juga sektor pangan tetapi yang masuk kategori penggunan pupuk non subsidi ( untuk pemilik lahan diatas 2 ha).

Melihat pada permasalahan tersebut sector perkebunan di Bantaeng dan Sulsel yang potensial untuk pupuk SRF NPK adalah perkebunan Kelapa Sawit, Kakao, Kopi, Tebu, Cengkeh dan karet. Sedang untuk tanaman pangan, perkebunan jagung juga merupakan pasar yang potensial.

\section{Tanaman Keras ( Perkebunan)}

Tanaman perkebunan yang potensial di wilayah Sulsel antara lain kelapa Sawit, Kakao, Kopi, Tebu, Cengkeh dan karet, dengan tingkat. kebutuhan pupuk diperkirakan sebesar 170.000 ton hingga 340.000 ribu ton/tahun.

Untuk wilayah Bantaeng sendiri luas areal perkebunan mencapai 9.786 ha dengan kebutuhan pupuk sekitar 4.000 ton/tahun, sedangkan untuk wilayah Kab. Bantaeng dan sekitar yang meliputi wilayah Jeneponto dan Bulukumba luas areal perkebunan mencapai 43.800 ha, dengan 
kebutuhan pupuk sekitar 17.520 ton/tahun. Untuk Bantaeng dan Jeneponto komoditas yang banyak adalah kakao, kopi dan cengkeh sedang karet ada di wilayah Bulukumba.Melihat pada kondisi tersebut maka target pasar untuk pupuk SRF NPK akan dikonsentrasikan pada wilayah Bantaeng dan sekitar (Jeneponto, Bulukumba).

Tabel 6.

Luas Lahan Perkebunan Dan Kebutuhan Pupuk Di Kabupaten Bantaeng ${ }^{4)}$

\begin{tabular}{lrrr}
\hline \multicolumn{1}{c}{ Komoditas } & $\begin{array}{c}\text { Luas Lahan } \\
\text { (ha) }\end{array}$ & $\begin{array}{c}\text { Perkiraan Kebutuhan } \\
\text { Pupuk (kg/ha) }\end{array}$ & \multicolumn{2}{c}{$\begin{array}{c}\text { Perkiraan Kebutuhan } \\
\text { Pupuk (Ton/Th) }\end{array}$} \\
\hline Kelapa Sawit & - & 400 & - \\
Kakao & 5.377 & 400 & 2.151 \\
Tebu (ton Gula) & - & - & - \\
Kopi & 3.800 & 400 & 1.520 \\
Cengkeh & 609 & 400 & 244 \\
Karet & - & - & - \\
Total & 9.786 & & 3.914 \\
\hline
\end{tabular}

Tabel 7.

Luas Lahan Perkebunan Sekitar Kab. Bantaeng ${ }^{4)}$

\begin{tabular}{|c|c|c|c|c|c|}
\hline \multirow[b]{2}{*}{ Komoditas } & \multicolumn{3}{|c|}{ Luas Lahan(ha) } & \multirow{2}{*}{$\begin{array}{c}\text { Perkiraan } \\
\text { Kebutuhan } \\
\text { Pupuk (kg/ha) }\end{array}$} & \multirow{2}{*}{$\begin{array}{c}\text { Perkiraan } \\
\text { Kebutuhan } \\
\text { Pupuk (Ton/Th) }\end{array}$} \\
\hline & Bantaeng & Jeneponto & Bulukumba & & \\
\hline Kelapa Sawit & - & - & & 400 & -- \\
\hline Kakao & 5.377 & 103 & 7.456 & 400 & 5.174 \\
\hline Tebu (Ton Gula) & . & & - & 400 & - \\
\hline Kopi & 3.800 & 2.438 & 5.197 & 400 & 4.574 \\
\hline Cengkeh & 609 & 201 & 4.621 & 400 & 2.172 \\
\hline Karet & & & 13.998 & 400 & 5.599 \\
\hline Total & 9.786 & 2.742 & 31.272 & & 17.520 \\
\hline
\end{tabular}

\section{Jagung, hortikultura}

Disamping untuk sektor perkebunan, potensi pemasaran pupuk SRF NPK juga diarahkan untuk tanaman jagung serta hortikultura seperti talas, buah buahan serta hobiis ( bunga dsb). Untuk tanaman jagung, adanya program penamanam jagung seluas 100.000 ha di wilayah Sulawesi bagian selatan, dengan koordinasi Pemkab Bantaeng akan menjadi pasar potensial ${ }^{3)}$. Demikian juga tanaman talas untuk ekspor ke Jepang yang dikembangkan di Kab. Bantaeng juga akan di arahkan untuk menggunakan pupuk SRF NPK.

Demikian juga secara umum untuk wilayah Sulsel, dengan masih rendahnya produktivitas rata rata tanaman jagung mengindikasikan bahwa sebagian lahan jagung belum menggunakan pupuk secara memadai.

\section{Analisis Ekonomi}

Sumber pendanaan untuk investasi usaha (CAPEX) maupun untuk biaya operasional usaha (OPEX) dapat dimobilisir dengan berbagai skenario. Sejumlah skenario yang umum dilakukan untuk pembiayaan investasi antara lain :

a. Equity ( modal sendiri )

b. Pinjaman.

Pembiayaan dengan equity ( modal sendiri ) dapat di lakukan oleh perseorangan maupun sebagai lembaga. Pembiayaan dari pinjaman dapat berasal dari lembaga perbankan maupun non perbankan.

Tabel 8.

Sumber Pendanaan

\begin{tabular}{ccc}
\hline Uraian & Prosentase & $\begin{array}{c}\text { Jumlah } \\
\text { (Juta Rp) }\end{array}$ \\
\hline Modal Sendiri & $30 \%$ & 3.618 \\
Pinjaman & $70 \%$ & 8.440 \\
Jumlah & $100 \%$ & 12.058 \\
\hline
\end{tabular}


Tabel 9.

Kebutuhan Pembiayaan/ Modal Investasi ( CAPEX)

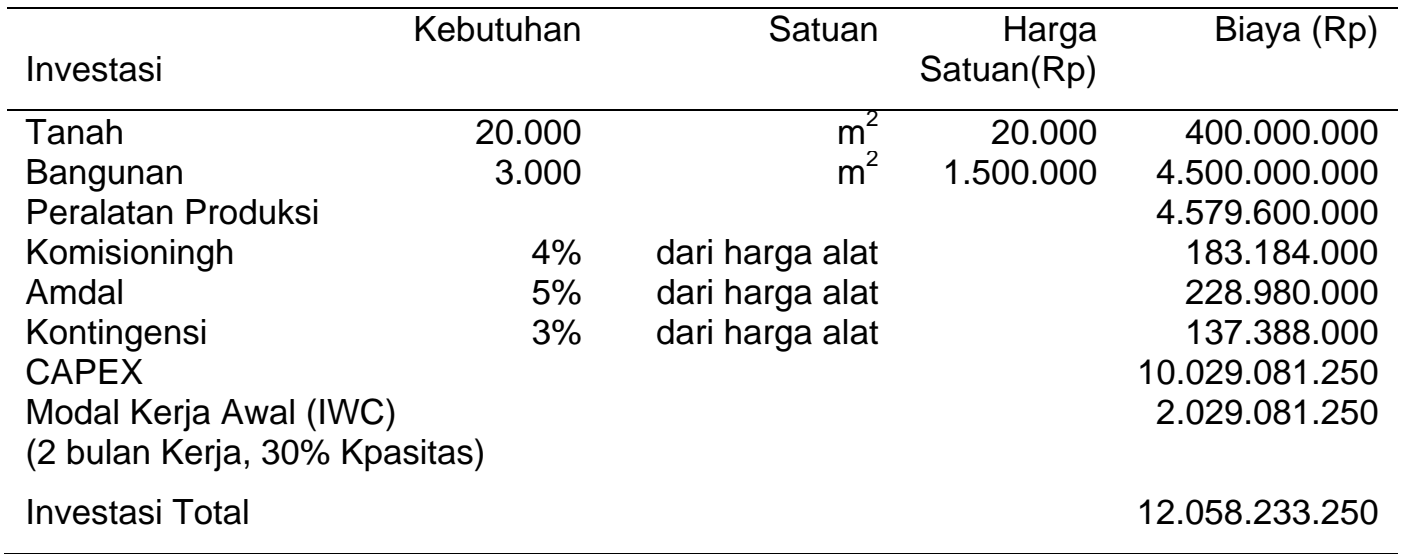

Sebagai bentuk usaha komersial dengan skala kecil/menengah dengan jumlah kebutuhan dana sekitar 10 milyard, dimungkinkan untuk membiayai investasi tersebut dengan $100 \%$ equity. Hal ini biasa dilakukan oleh investor jenis lembaga/ perusahaan yang terkait dengan produk pupuk. Perusahaan perkebunan, perusahaan kehutanan ataupun perusahaan pupuk nasional dapat melakukan investasi dengan $100 \%$ equity dari dana perusahaan tersebut.

Investasi juga dapat dilakukan dengan modal pinjaman, dengan equity sekitar 30\% perusahaan dapat meminjam kepada lembaga perbankan maupun institusi keuangan lain untuk mendanai usaha tersebut. Untuk memperkecil resiko usaha maka akan lebih baik jika saham usaha dimiliki lebih dari dua pihak.

Tabel 10,

Harga Pokok Produksi (HPP)

\begin{tabular}{|c|c|c|c|c|}
\hline \multirow[b]{2}{*}{ Komponen Biaya } & \multicolumn{4}{|c|}{ Total Biaya (Rp) } \\
\hline & $\begin{array}{c}\text { Harga Urea } \\
4.100\end{array}$ & $\begin{array}{c}\text { Harga Urea } \\
3.200\end{array}$ & $\begin{array}{l}\text { Harga Urea } \\
2.200\end{array}$ & $\begin{array}{c}\text { Harga Urea } \\
1.800\end{array}$ \\
\hline \multicolumn{5}{|l|}{$\begin{array}{l}\text { Biaya Bahan Baku } \\
\text { BB Utama: }\end{array}$} \\
\hline Urea & 14.350 .000 .000 & 11.200 .000 .000 & 7.700 .000 .000 & 6.300 .000 .000 \\
\hline Zeolit & 2.816 .000 .000 & 2.816 .000 .000 & 2.816 .000 .000 & 2.816 .000 .000 \\
\hline DAP & 14.105 .000 .000 & 14.105 .000 .000 & 14.105 .000 .000 & 14.105 .000 .000 \\
\hline $\mathrm{KCl}$ & 10.855 .000 .000 & 10.855 .000 .000 & 10.855 .000 .000 & 10.855 .000 .000 \\
\hline \multicolumn{5}{|l|}{ BB Pembantu } \\
\hline Binder & 300.000 .000 & 300.000 .000 & 300.000 .000 & 300.000 .000 \\
\hline Karung & 400.000 .000 & 400.000 .000 & 400.000 .000 & 400.000 .000 \\
\hline Biaya Upah & 534.000 .000 & 534.000 .000 & 534.000 .000 & 534.000 .000 \\
\hline $\begin{array}{l}\text { Biaya Operasi Mesin } \\
\text { (listrik + Air) }\end{array}$ & 328.500 .000 & 328.500 .000 & 328.500 .000 & 328.500 .000 \\
\hline Overhead & 43.125 .000 & 43.125 .000 & 43.125 .000 & 43.125 .000 \\
\hline Total Biaya Produksi & 43.731 .625 .000 & 40.581 .625 .000 & 37.081 .625 .000 & 35.681 .625 .000 \\
\hline $\begin{array}{l}\text { Harga Pokok Produksi / } \\
\text { HPP (Rp/kg }\end{array}$ & 4.373 & 4.058 & 3.708 & 3.568 \\
\hline
\end{tabular}


Analisis kelayakan dan sensitifitas ( Harga jual, Harga Urea dan harga Zeoilte)

\section{Indikator kelayakan}

Indikator kelayakan (IRR, NPV dan Pay Back Periode) diperhitungkan dengan asumsi:
Harga Urea
Harga Zeolite
Rp. 3.200,-/kg
Harga jual produk
: Rp. $1.100,-/ \mathrm{kg}$
: Rp. $4.600,-/ \mathrm{kg}$

Maka dihasilkan indikator kelayakan sebagai berikut :

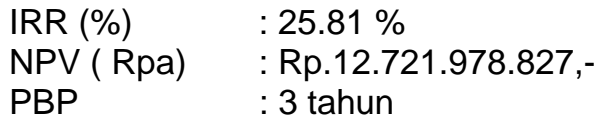

\section{Analisis sensitivitas (IRR vs harga zeolite)}

Harga urea Rp.2.200,-/kg
Kedua grafik pada Gambar 2 dan Gambar 3 menunjukkan bahwa harga zeolite serta harga urea sebagai bahan baku utama sangat dominan dalam pergerakan tingkat kelayakan usaha. Dengan demikian sensitifnya tingkat kelayakan usaha dengan harga kedua komponen tersebut maka manajemen usaha harus mengatur strategi agar kedua harga tersebut dapat dijaga stabil. Tidak stabilnya harga kedua komponen tersebut akan berpengaruh pada kondisi aliran kas (cash flow) yang jika tidak dikelola secara hati hati akan dapat merusak aliran kas perusahaan yang pada gilirannya akan mengganngu kinerja perusahaan.

Salah satu metode untuk mengantisipasi perubahan harga kedua komponen tersebut perusahaan harus mempunyai persediaan bahan tersebut secara cukup atau dengan melakukan kontrak/perjanjian dengan supplier bahan baku tersebut.



Harga Zeolite

Gambar 2.

Analisis Sensitivitas Harga Urea Rp 2.200,-/kg

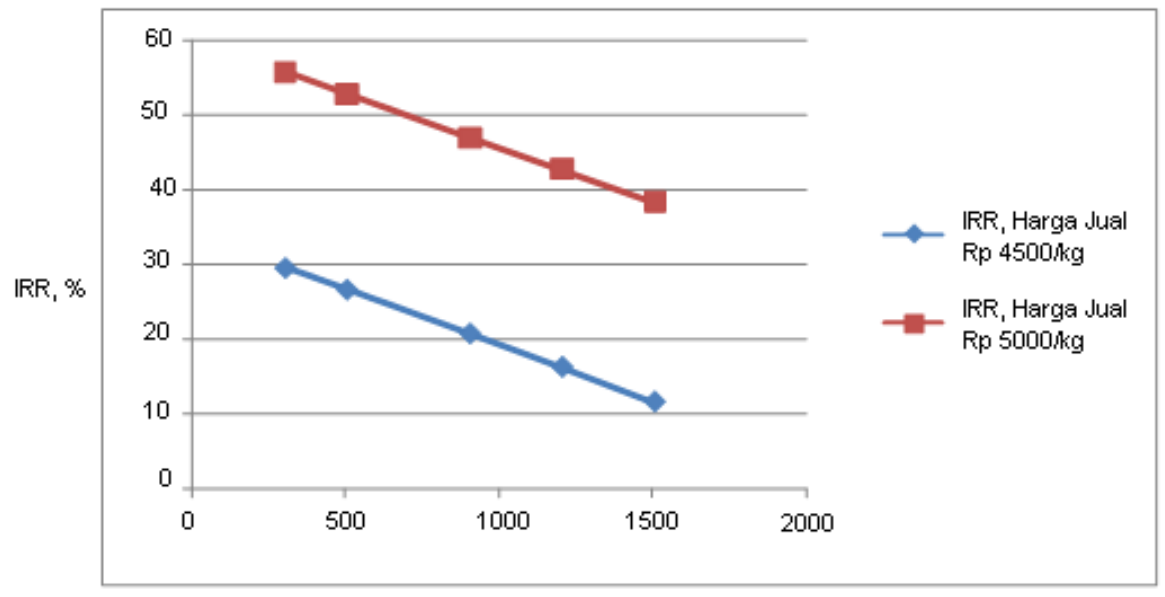

Harga Zeolite (Rp/kg)

Gambar 3.

Analisis Sensitivitas Harga Urea Rp 3.200,-/kg 


\section{Dampak ekonomi pada wilayah sekitar}

Setiap aktifitas yang meningkatkan nilai tambah, akan memberikan pengaruh positif pada pertumbuhan ekonomi wilayah dimana aktifitas tersebut dilakukan. Penerapan teknologi pupuk SRF NPK di wilayah Kabupaten Bantaeng, Sulawesi Selatan akan memberikan efek berantai, mulai dari sectorsektor yang terkait langsung maupun sektor yang tidak terkait secara langsung.

Secara umum dari kegiatan penerapan pupuk SRF NPK ada beberapa aktifitas ekonomi sebagai berikut :

1. Aktifitas pengadaan bahan baku,

2. Aktifitas konstruksi peralatan pabrik,

3. Aktifitas proses produksi,

4. Aktfitas distribusi/ perdagangan produk, dan

5. Aktifitas penggunaan pupuk di sektor terkait.

Proses pengadaan bahan baku berupa zeolite diharapkan dapat mendorong pemanfaatan potensi zeolite yang ada di wilayah Sulawesi yang selama ini belum digarap. Sehingga usaha pertambangan zeolite akan dapat menjadi aktifitas ekonomi sendiri yang dapat menciptakan lapangan kerja.

Proses konstruksi peralatan pabrik akan memberikan aktifitas ekonomi pada pada UKM konstruksi, karena teknologi yang diterapkan dapat dilakukan oleh perusahaan konstruksi setempat. Secara langsung hal ini akan menyerap tenaga kerja serta memerlukan material untuk pembangunannya.

Proses produksi secara langsung akan menciptakan lapangan kerja yang bersifat continue, mulai tanaga langsung diproses produksi dan juga tenaga tidak langsung untuk pemasaran, penjualan, serta lapangan tidak langsung lain seperti agen pupuk.

Penggunaan pupuk oleh petani, perkebunan akan meningkatkan produktifitas lahan sehingga pendapatan petani dapat ditingkatkan. Dari seluruh aktifitas tersebut secara program, diharapkan penerapan teknologi pupuk SRF NPK di sektor pertanian dan perkebunan Kabupaten Bantaeng dapat memberikan hal-hal positif sebagai berikut :

1. Mendorong petani untuk menggunakan pupuk majemuk ( SRF NPK) sehingga dapat membantu untuk mengurangi penggunaan urea serta memperbaiki struktur lahan pertanian

2. Mendorong petani tanaman keras untuk menggunakan pupuk majemuk dalam peningkatan produktifitas tanaman
3. Penghematan penggunaan tenaga kerja, yaitu dengan pola waktu pemberian pupuk yang efektif

4. Meningkatkan produktifitas tanaman yang pada akhirnya akan dapat meningkatkan output produk wilayah kab. Bantaeng.

5. Meningkatkan pendapatan petani

6. Meningkatkan aktifitas ekonomi terkait efek berantai (multiplier effect) akibat keberadaan pabrik pupuk SRF NPK.

7. Meningkatkan PAD Kab. Bantaeng

\section{SIMPULAN}

Produk pupuk SRF NPK yang dihasilkan pabrik pupuk SRF di Kab. Bantaeng akan mengambil target pasar pada pasar pupuk non subsidi di sektor perkebunan di wilayah Bantaeng, Jeneponto dan Bulukumba. Disamping itu juga untuk tanaman hortilkultura serta tanaman jagung. Pengadaan urea sebagai bahan baku untuk pupuk SRF NPK akan diusahakan untuk dapat dipenuhi dari PT. Pupuk Kalimantan Timur, untuk itu harus dilakukan pendekatan bisnis untuk menjamin ketersediaan urea dengan harga yang sesuai dengan analisis keuangan.Pengadaan DAP, KCL sebagai sumber $\mathrm{P}$ dan $\mathrm{K}$, akan di penuhi dari distributor bahan tersebut. Pengadaan Zeolit, untuk tahap awal akan di penuhi dari perusahaan tambang zeolite di Jawa (Malang, Sukabumi), sebelum potensi zeolite yang ada di Mamasa dan Maros di tambang secara komersial. Untuk operasional pabrik pupuk SRF NPK, ada beberapa alternative bentuk organisasi usaha yang mungkin diterapkan, antara lain : UPTD (BLU), PERUSDA, Kerjasama Mitra ( Seperti dengan PT. PKT), dll. Untuk menjamin ketersediaan bahan baku serta tersedianya sistem pemasaran yang baik, kerjasama dengan perusahaan pupuk seperti PT.PKT akan sangat membantu kelancaran operasional usaha. Jika dimungkinkan, pabrik pupuk SRF NPK dapat menjadi anak perusahaan PT.PKT dengan pembagian saham yang diatur secara $B$ to $B$. Perencanaan keuangan pabrik SRF NPK di Kab. Bantaeng sbb : Kebutuhan investasi : Rp. 12.058.000.000,-, yang terdiri atas modal tetap (Capital Expenditure sebesar Rp. 10.029.000.000,- dan modal kerja awal /IWC sebesar Rp. 2.029.000.000,-) Indikator kelayakan (IRR, NPV dan Pay Back Periode) diperhitungkan dengan asumsi : 
Harga Urea : Rp. 3.200,-/kg Harga Zeolite: Rp. 1.100,-/kg Harga jual produk :Rp. 4.600,$/ \mathrm{kg}$ Indikator kelayakan sebagai berikut : IRR (\%) :25.81\% NPV( 10\%) :Rp.12.721.978.827, PBP: 3 tahun. Pada awal operasional usaha (tahun 1-3) diperlukan sejumlah kebijakan dari pemerintah (Pemkab) antara lain :1. Tahun 1-2 diterapkan pola inkubasi teknologi, sehingga operasional usaha belum di berlakukan sebagai perusahaan komersial secara penuh. 2. Produk yang dihasilkan pada tahun tahun awal, dilakukan subsidi oleh Pemkab untuk kegiatan demplot/ demfarm sebagai bagian dari sosialisasi dan strategi komersialisasi. Penerapan teknologi pupuk SRF NPK di wilayah Kab. Bantaeng , Sulawesi Selatan akan memberikan efek berantai, mulai dari sektor sektor yang terkait langsung maupun sektor yang tidak terkait secara langsung.

\section{UCAPAN TERIMA KASIH}

Kajian dalam penelitian ini merupakan salah satu hasil dari kegiatan DIPA Pusat Teknologi Industri Proses- BPPT dengaan kegiatan "Pupuk Berimbang", bekerjasama dengan pemerintah kabupaten Bantaeng Sulawesi Selatan.

\section{DAFTAR PUSTAKA}

1. Dyer, A., An Introduction to zeolite molecular sieves and fertilizer matrix, John Wiley \& Sons, UK, 1988.Iman Soeharto, Manajemen dan Kelayakan Proyek, tahun 1997

2. ................, Keputusan Gubernur Sulawesi Selatan No. 1353/VI/TAHUN 2013 tentang Realokasi kebutuhan pupuk bersubsidi untuk sektor pertanian Prov. Sulawesi Selatan, tahun 2013

3. ...................., Keputusan Bupati Bantaeng No. 52/92/I/2013 tentang Penetapan Rencana Kebutuhan Pupuk Kab. Bantaeng , Tahun 2013

4. ...................., Data Komoditi daerah, Badan Koordinasi Penanaman Modal (BKPM) , 2012

5. ............., Rencana Alokasi Pupuk Bersubsidi di Kab/Kota se Prov. Sulawesi Selatan, tahun 2013. 